\title{
Football in Uzbekistan: Law, Leisure and Sociology
}

Nigora Sabirjanovna Abdikadirova ${ }^{1 *}$, Djamilya Sayfiyevna Nurillaeva ${ }^{1}$, Mukhabbat Ganijanovna Azamova $^{1}$, Salomatjon Rajabovna Jabborova ${ }^{1}$, Boburbek Kudratovich Bobomuradov ${ }^{1}$, Izzatbek Khushnudovich Kutlimuratov ${ }^{1}$

${ }^{1}$ Uzbek State University of Physical Culture and Sports, Chirchik city, Uzbekistan.

*nigoraabdikadirova@uzdjtsu.uz

\section{ABSTRACT}

Relevance. In the process of development of the country, the value system plays an important role, to participate in politics and sports, to acquire a place in the world community. This will require specialists who carry out certain missions in these areas. Football is one such medium that works at the micro and macro levels.

Aim. This article was written with the aim of analysing the place of football in public and private life, socialization, in organizing people's leisure time, the situation of football in Uzbekistan, problems and their solutions.

Methods. Scientific methods were applied such as working with documents, comparative analysis, literature review, questionnaires, statistics, etc.

Results. As a result of the survey, the problems of football in the country and the decisions taken to eliminate them were clarified, as well as the role of football in leisure and socialization of the individual.

Conclusion. In the conclusion, conclusions are given on this topic.

Keywords

Football; Law; Leisure; Youth; Socialization.

Article Received: 18 October 2020, Revised: 3 November 2020, Accepted: 24 December 2020

\section{Introduction}

The experience of many countries shows that state care for the fate of national sports and physical culture certainly turns into multiple benefits. After all, the support of these articles of the social sphere first of all creates all the necessary prerequisites for the moral and physical improvement of the youth and youth environment of society.

It is symbolic that Uzbekistan does not fall out of the category of countries where there is an understanding of the importance of this truth. Government structures, public organizations, sports departments of the country always work together in solving such important problems as the progressive development of the material and technical base of the sphere of sports and physical culture, the achievement of mass participation in their organization, strengthening the base of the professional sector, and others.

Over the years of independence, the Cabinet of Ministers of the Republic has adopted more than ten resolutions aimed at further developing the sports movement by creating new societies, building sports facilities, developing conditions for the professionalization of various groups of athletes ... Over the years of sovereign development, the country's representatives at the Olympic Games and championships and Asian Cups, Asian Games and other major international competitions won 731 gold, 736 silver and 845 bronze medals. This is undeniably impressive ...

The main work on the development of sports in the republic is carried out by the Ministry of Culture and Sports of the Republic of Uzbekistan. Along with it, measures for the further development of the Olympic movement and the participation of the republic's athletes in it are provided by the National Olympic Committee, which since 1993 has become a member of the International Olympic Movement.

Currently, in 32 sports, national federations of Uzbekistan are members of international federations, having secured the right to participate in international competitions of various kinds. 
The training of specialists in physical culture and sports is carried out by the Uzbek State Institute of Physical Culture. About 2 thousand students study there annually. The higher educational institution prepares physical education teachers and sports instructors.

In recent years, individual sports have been developing at an accelerated pace in the republic, the material and technical base of which is being modernized considering the requirements accepted in the world. In this series, the base of Uzbek football is indicative, where the participation of 36 teams is recorded. They have 231 stadiums, 5231 football fields, as well as numerous playgrounds for mini-football and futsal. The most popular sport in the republic is the Championship and the Championship of Uzbekistan, the Cup of the Republic.

In 1928, for the first time, the national team of Uzbekistan was created, which took part in the Spartakiad, the participants of which included representatives of European countries. At this tournament, the national team of Uzbekistan played its first international match against the national team of workers' clubs of Switzerland and won with a score of 8: 4.

Until 1992, the national team of Uzbekistan met irregularly with different age restrictions and played about 80 matches at the Spartakiads, and also participated in friendly games.

The national team of Uzbekistan of the new convocation played its first matches in 1992. These matches are officially registered by FIFA on the basis that the Uzbekistan national team has been allowed to participate in tournaments held under the auspices of FIFA since 1992. In 1992, the first Central Asian Cup was held, initiated by FIFA.

In 1994, the Football Federation of Uzbekistan was officially admitted to FIFA.

\section{Review}

\section{Legal framework for the development of football}

Football Association of Uzbekistan, abbr. FAU (Uzbek. O'zbekiston futbol assotsiatsiyasi /
Uzbekiston football association) is an organization that controls and manages football in Uzbekistan. $\mathrm{He}$ is engaged in organizing and managing the national teams of the country, supporting, developing and popularizing football in the territory of Uzbekistan.

Since its foundation in 1992, and until January 25, 2018, it was called the "Football Federation of Uzbekistan" (Uzbek. O'zbekiston futbol federatsiyasi / Uzbekiston football federation).

Until 2009, the Football Federation of Uzbekistan controlled all football in Uzbekistan, including the national teams and the Championships of Uzbekistan. But in 2009, another football organization was created in Uzbekistan - the Professional Football League of Uzbekistan (PFL of Uzbekistan), which began to manage and control the Championships of Uzbekistan, leaving the Football Federation of Uzbekistan only control over the national teams of Uzbekistan. At the same time, the PFL of Uzbekistan is subordinate to the Football Association of Uzbekistan.

The headquarters of the Football Association of Uzbekistan is located in the center of Tashkent, on Islam Karimov Street (formerly Uzbekistan Street), house 98A.

History. The Football Association of Uzbekistan was organized in 1946 as the "Football Federation of the Uzbek SSR" - a branch of the Football Federation of the USSR. After gaining independence by Uzbekistan, in 1992 it was reorganized into the "Football Federation of Uzbekistan". In 1994, FFU was admitted to FIFA and AFC. The federation had the opportunity to join UEFA, but this idea was rejected for unknown reasons, and FFU joined the AFC, thus becoming a member of the Asian football family. Although the Football Federation of Uzbekistan was admitted to FIFA and AFC in 1994, the Uzbekistan national team was allowed to play international friendly matches held under the auspices of FIFA since 1992. In 1997-2013, the Football Federation of Uzbekistan was part of one of the subfederations of the AFC - the Football Federation of Central and South Asia, which at 
that time united the Football Federation of Central and South Asian countries (currently this subfederation is called the Football Federation of South Asia and unites only countries South Asia). Since June 2014, the Football Association of Uzbekistan has been a member of the new AFC subfederation - the Football Federation of Central Asia, which unites the football federations of Afghanistan, Iran, Kyrgyzstan, Tajikistan, Turkmenistan and Uzbekistan.

On January 7, 2013, at a ceremony organized by FIFA in Zurich, Switzerland, the Football Federation of Uzbekistan was awarded the "Fair play" prize (prize for fair play) from FIFA. The reason for the victory of the Football Federation of Uzbekistan in this nomination was the minimum number of yellow and red cards among the players of the national team of Uzbekistan, which took first place in Fair play points among the representatives of the AFC.

On January 25, 2018, during an extraordinary reporting and election conference of the FFU, it was decided to transform the Football Federation of Uzbekistan (FFU) into the Football Association of Uzbekistan (FAU). Achilbay Ramatov was elected the new president.

The head of the Football Association of Uzbekistan is the president. Since July 15, 2019, the President of the FAU is Abdusalam Azizov. The actual and executive head of the association is the first vice president, whose post has been held by Ravshan Irmatov since June 2019. The rest of the vice-presidents: Mukhiddin Dzhuraev and Shoakram Israilov. Secretary General - Avaz Maksumov (Wikipedia).

\section{The state of football now. Systemic problems}

Recently, Uzbekistan has nothing to boast about in national football: either at the level of the national team or at the level of clubs: "The audience is shrinking, but most importantly, there is no continuity - the necessary training of children and young men."

As noted in the presidential decree, the following systemic problems hinder the development of football in the country:
- the system of selection and selection of gifted children and adolescents does not meet modern requirements, and national teams lack high-quality sports reserves;

- low level of physical fitness of players and noncompliance with international standards. For example, no national or Olympic footballer has passed the Yo-Yo test, which measures endurance and recovery after completing it;

- ineffective use of marketing and modern mechanisms in the management and development of football;

- lack of conditions for meeting the needs in the system of qualified personnel, such as "football analyst", "sports breeder" ("scout"), "sports manager", "sports marketer", "sports doctor", "sports psychologist", "sports pharmacologist "," sports nutritionist "and" sports lawyer ";

- low level of the educational process and competition among children and youth football teams in the regions;

- low social status and prestige of coaches in children's and youth football, and the system of payment and material incentives does not meet today's requirements;

- weak work of regional football associations in the development of football, organizing football events, attracting young people to football and promoting;

- the state of the football infrastructure (football pitches, lighting system, multimedia equipment, stands for fans) does not meet modern requirements, and the sports equipment intended for training camps is outdated;

- lack of a single training center for national football teams, which would allow for a centralized training process and competitions;

- lack of centers for functional diagnostics and rehabilitation of football players, a system of pharmacological support and scientifically based methodology;

- the legal status of football clubs and a clear mechanism for ensuring the transparency of football matches in national championships are not defined; 
- The activities of most professional football clubs do not meet the requirements of the Asian Football Confederation and other international standards;

- ineffective use of funds allocated for the development of football;

- the presence of such negative cases as artificial decrease in the biological age of athletes participating in international and national football competitions;

- presence of corruption schemes and contractual games in football, as well as the lack of a transparent control system (Latipov, 2018).

\section{Football Development Program 2018-2022}

President Shavkat Mirziyoyev, by a decree of March 16, approved the Program for the further development of football in the Republic of Uzbekistan for 2018-2022 (Lex.uz, 2018).

By the decree, the Bunyodkor stadium with the entire complex of buildings and structures in Tashkent was determined as the main base of the Football Association of Uzbekistan for organizing the training process of national football teams and holding sports competitions and other events.

On the basis of state specialized boarding schools for football in the regions and Tashkent, 14 children and youth football academies were established, as well as the Republican Children and Youth Football Academy (it will be located at the Bunyodkor stadium) under the Football Association.

Since 2018, the Academies have been selecting (selecting) promising young football players for their further professional training and creating a high-quality sports reserve for national teams and professional football clubs.

The remaining boarding schools for football were redesigned into state specialized boarding schools for other Olympic and national sports, including games, considering the need and priority of the development of sports in the regions.

The Republican School of Football Coaches and Referees under the Ministry of Physical Culture and Sports has been abolished, the Football Association has been assigned the authority to train, retrain and improve the qualifications of football coaches and referees. The Football Support Fund of Uzbekistan and its branches in the capital and regions are being liquidated.

By the decree, the Football Association with territorial subdivisions, the public association "Professional Football League of Uzbekistan" and professional football clubs are exempted until January 1, 2023 from paying all types of taxes and mandatory contributions to state trust funds, as well as customs payments (except customs duties) for imported sports equipment, inventory and special professional sports equipment, vehicles, including special ones, not produced in Uzbekistan (according to the approved lists).

Foreign specialists attracted by the Football Association, PFL and professional clubs are exempt from personal income tax for the same period (Latipov, 2018).

\section{Concept for the development of football until 2030}

An increase in the number of football coaches and coaches, the filling of stadiums with spectators, a unified system of electronic tickets and season tickets, the creation of school leagues, VAR, bookmaking and others - the president approved the Concept for the development of football until 2030 (Latipov, 2019).

On December 4, 2019, President Shavkat Mirziyoyev signed a decree "On measures to raise football to a completely new stage in the development of football in Uzbekistan." The document approved the Concept for raising to a new stage in the development of football in the republic until 2030 (Lex.uz, 2019).

To turn football into the most popular sport, the Concept was approved to raise football to a new stage in the development of football in the republic until 2030.

According to the concept, by this time the number of regularly playing football should increase to $5 \%$ (now $0.14 \%$ ), the national team should enter the top 50 of the rating of the best national teams of the International Federation of Football Associations (FIFA). 
It also envisages a gradual increase in the number of private football schools, the organization and holding of championships and official international tournaments included in the classification of FIFA and AFC.

The document envisages the creation of 6 football schools and 9 children and youth sports schools under the Ministry of Physical Culture and Sports on the basis of 15 children and youth football schools under professional football clubs, funded from the state budget.

The decree pays special attention to the training of coaches and referees - it is planned to create a center for training football specialists at the AFU. At the center, specialists will improve their qualifications in the areas of "coach", "selector" (scout), "analyst", "judge", "marketer" and "football manager".

Starting from the 2020/2021 academic year, training will begin in relevant educational institutions of qualified specialists in the areas of "sports doctor", "sports psychologist", "sports pharmacologist", "sports lawyer" and "sports nutritionist".

From the football season 2021, it is planned to introduce the VAR system (Video Assistant Referee, video assistant to the referee) to ensure fairness and transparency of meetings between Super League teams based on international experience.

The decree gives permission to introduce betting activities from January 1, 2021 by obtaining a license from the Capital Market Development Agency.

The activities of football agents (intermediaries) will be streamlined. The Football Association is entrusted with the authority to accredit them to train football players with high sports potential at a professional level, to ensure their professional activities in prestigious football clubs in foreign countries, as well as to protect the rights and interests of football players based on international requirements.

In addition, the document stipulates that the "Football League of Schools" competition will be held on an ongoing basis between the secondary schools of each district (city) at least 2 times a year. Based on their results, the selection (selection) of gifted students will be carried out to the football departments of children and youth sports schools in districts (cities) and private football schools.

The Football League of Sports Schools competition will be held between the football departments of youth sports schools of districts (cities) and private football schools. Based on their results, the best football players will be selected for football skill schools, private professional football schools and football academies at professional football clubs.

Moreover, it is planned to hold the "League of Professional Football Schools" competitions between football schools, private professional football schools and football academies at clubs. Based on the results, players will be selected for regional professional football clubs (Lex.uz, 2019).

In 2020-2021, a training center for national football teams will be created on the territory of the Yangibazar village of the Yukorichirchik district of the Tashkent region, as well as a modern sport and medical center at the AFU for functional diagnostics, rehabilitation and rehabilitation of athletes and equipping it with the necessary medical equipment and inventory (Latipov, 2019).

Until 2030, on the basis of a public-private partnership, it is planned to build and reconstruct football stadiums, which will have to meet the requirements of FIFA and the AFC. In addition, it is expected to introduce a unified system of electronic tickets and season tickets for visiting stadiums.

\section{The place of football in organizing the leisure of youth}

Leisure is an important component of the free time of young people, which a young person has at his own discretion. Football is one of the most widespread sports for organizing the leisure of modern youth (Akimova, 2003). 
Now, out of 33.6 million Uzbeks, more than 327,291 people play football (of which 11,884 are women). The number of footballers aged 7-18, who are involved in 297 sports institutions, is 45,919 people (including 610 women), professional footballers - 2,220 (400 women). Only $0.14 \%$ of the population regularly plays football (Latipov, 2019).

As of 2019, the republic has 255 sports schools for the development of football, 209 children and youth sports schools, 14 children and youth academies, 15 football schools at professional clubs and 17 private schools. For comparison, in Great Britain the number of football schools and academies has approached 40 thousand, and of 65 million people - 11.5 (20\%) regularly play football. There are 27336 football educational institutions in Germany, of 81 million people, more than 16 million (20\%) train constantly (Latipov, 2019).

According to the presidential decree adopted in 2018 , in order to train young football players and organize leisure activities for young people, within two months, a draft government decision was developed to approve the program "Football ground in every makhalla" (makhalla - type of local government system in Uzbekistan), which provides for the construction of football grounds in makhallas, including on the terms private partnership. On the basis of the recreation area "Sizhzhak" in the Bostanlyk district of the Tashkent region, which the court turned to the state revenue, a training base was created under the Football Association for national teams. The deputy chairmen of citizens 'assemblies consultants on youth issues - are entrusted with the functions of heads of the commissions of citizens' assemblies on minors, youth and sports. They are involved in promoting football and other sports, instilling a healthy lifestyle, as well as organizing the selection (selection) of promising and gifted children and youth among the residents of makhallas. In addition, they assist in the improvement of football grounds and other sports facilities in makhallas.

\section{The role of football in the socialization of youth} Socialization of the individual is carried out in various situations resulting from the influence of many factors, the combined influence of which requires a certain behaviour and activity from a person (Shilko, 2018). In sociology, there are two levels of socialization: primary and secondary.

Primary socialization occurs in the sphere of interpersonal relations in small groups, the agents of which are the immediate environment of the individual: parents, close and distant relatives, friends, peers, teachers, doctors, etc.

Secondary socialization occurs in large social groups and institutions, representatives of various organizations and official institutions act here as agents of socialization: administrations of secondary schools, universities, scientific and professional associations, as well as the army, the state, etc. (Abdikadirova, 2020)

In recent decades, in connection with the penetration of sports into almost all spheres of modern society, its value as a factor of socialization and education of the individual is increasing. The totality of various interhuman relations that arise and are manifested in sports activity forms the basis of the formative influence of sport on the personality, assimilation of social experience by it in the field of sports, and through it the general human social experience. Techniques, abilities and skills, personal qualities, formed as a result of sports, are used in other activities that are not directly related to sports (Shilko, 2018).

This direction of personality socialization under the influence of V.I. Stolyarov calls "socialization through sports" (Stolyarov, 2005). As one of the socializing factors, in the process of playing football, goals and objectives are realized that go beyond sports activities and affect all socially significant areas of personal development such as: physical education and improvement, cognitive, emotional, psychosocial, etc.

Nowadays, football has become a very effective tool for socialization, so that such influential public institutions as schools, universities, 
political parties, administrative structures of various levels effectively use this activity in order to achieve social and other goals. A constant longterm training process, strong-willed and psychological training, competitive experience, the ability to self-education and self-improvement are effective prerequisites for the formation of professional competencies and effective performance of a specialist's work in other areas of activity.

The acquisition of mobilization values by a person in the process of sports activity is of great importance for the preparation of a viable and socially active personality:

- the ability to rationally organize your time;

- internal discipline;

- composure;

- quickness of situation assessment;

- making an adequate decision;

- persistence in achieving the set goal;

- the ability to calmly survive failure;

- find a way out of a difficult situation.

Through football, the principle of modern life is implemented - "rely on yourself and the group that supports you." This means that the achievement of success depends, first of all, on the personal, individual qualities of the individual - ambition, initiative, discipline, hard work, patience and other qualities that are formed under the influence of sports activities, and the role of the group, which will give public opinion for the individual, is important.

A person playing football, first of all, changes his lifestyle, which from that moment is more subordinate to the formation of knowledge, skills, and the realization of interests and needs related to competitive activity and preparation for it (Zakharov, 2008). As sports practice shows, the effectiveness of acquiring skills for inclusion in football depends on the creative activity of the individual, his successful introduction to social norms, social roles in the field of sports and the values of sports culture. The effectiveness of socialization through football also depends on how the values of sport coincide with the values of society and the individual.

\section{Conclusion}

In the process of writing this article, we considered several factors, history, law, strategies related to the development of football and personality, and gave a brief overview in these areas such as:

- legal framework for the development of football;

- history of the organization of the Football Association of Uzbekistan;

- the situation of football in Uzbekistan at this time and systemic problems in football;

- the football development program for 20182022;

- Concept for the development of football until 2030;

- the place of football in the organization of youth leisure;

- The role of football in the socialization of youth.

Of course, these problems need wider coverage and it is necessary to conduct separate studies, which are planned to be carried out in the future.

\section{References}

[1] Sabirdjanovna, A.N. (2020). Mechanisms of Forming a System for Organization of Leisure of Youth of Modern Uzbekistan.

[2] International Journal of Psychosocial Rehabilitation, 24(4): 469-476, DOI: 10.37200/IJPR/V24I6/PR260051

[3] Akimova D.A. (2003). Sociologija dosuga. Moscow.

[4] Futbol'naya assotsiatsiya Uzbekistana. Available at: https://ru.wikipedia.org/wiki/Futbol'naya assotsiatsiya Uzbekistana

[5] Latipov, Sh. (2018). Prinyata programma razvitiya futbola na 2018-2022 gody. Gazeta.uz, March, 16. Available at: https://www.gazeta.uz/ru/2018/03/16/footb all-doc/

[6] Latipov, Sh. (2019). Utverzhdena Kontseptsiya razvitiya futbola do 2030 
goda. Gazeta.uz, June, 12. Available at: https://www.gazeta.uz/ru/2019/12/06/footb all/

[7] Miskevich A.B. (1989). Chelovek v svobodnoe vremja: mnenie sociologa. Minsk.

[8] merakh po dal'neishemu razvitiyu futbola. (2018). Postanovlenie Prezidenta Respubliki Uzbekistan №PP-3610 16.03.2018. Available at: https://lex.uz/docs/3589857

[9] merakh po podnyatiyu na sovershenno novyi etap razvitiya futbola v Uzbekistane. (2019). Ukaz Prezidenta Respubliki Uzbekistan №UP-5887 04.12.2019. Available at: https://lex.uz/docs/4631213

[10] Shil'ko V.G. (2018). Sotsiologiya fizicheskoi kul'tury. Tomsk.

[11] Stolyarov V.I. (2005). Sotsiologiya fizicheskoi kul'tury $i$ sporta. Tutorial. Moscow, Fizicheskaya kul'tura.

[12] Uzbekiston Respublikasini yanada rivojlantirish bo'yicha Harakatlar strategiyasi tugrisida. (2017). Uzbekiston Respublikasi Prezidentining 2017 yil 7 fevraldagi PF-4947 son gi Farmoni. Available at: $\underline{w w w . l e x . u z}$.

[13] Zakharov M. (2008). Sotsiologiya sporta. Smolensk. 